Hydrol. Earth Syst. Sci. Discuss., https://doi.org/10.5194/hess-2017-532

Manuscript under review for journal Hydrol. Earth Syst. Sci.

Discussion started: 24 October 2017

\title{
Optimizing micro watershed management for soil erosion control under various slope gradient and vegetation cover conditions using SWAT modeling
}

\author{
Ghulam Nabi ${ }^{1}$, Fiaz Hussain ${ }^{2}$, Ray-Shyan $\mathrm{Wu}^{3}$, Vinay Nangia ${ }^{4}$, Riffat Bibi ${ }^{5}$, Abdul Majid ${ }^{6}$
}

$5{ }^{1}$ Assistant Professor, Centre of Excellence in Water Resources Engineering, University of Engineering and Technology, Lahore, Pakistan, gnabi60@yahoo.com

${ }^{2} \mathrm{PhD}$ Candidate, Department of Civil Engineering, National Central University, Taiwan. Lab Engineer, PMAS-Arid Agriculture University Rawalpindi, Pakistan, 105382602@cc.ncu.edu.tw

${ }^{3}$ Professor, Department of Civil Engineering, Water Resource Engineering Group, National Central University, Taiwan.

10 raywu@ncu.edu.tw

${ }^{4}$ Agricultural Hydrologist, The International Centre for Agriculture Research in the Dry Areas (ICARDA) V.Nangia@cgiar.org

${ }^{5}$ Assistant Research Officer (Soil Science) Soil and Water Conservation Research Institute (SAWCRI) riffat_ises@yahoo.com ${ }^{6}$ Senior Professional Officer \& Country Manager Pakistan, The International Centre for Agriculture Research in the Dry Areas

15 (ICARDA) a.majid@cgiar.org

Correspondence to: Fiaz Hussain (engr.fiaz@uaar.edu.pk )

Abstract. This study evaluated parameters of soil erosion and optimization of micro watersheds by applying a semidistributed basin-scale Soil and Water Assessment Tool (SWAT) model in various small watersheds of the Chakwal and Attock districts of Pothwar, Pakistan. The model was calibrated and validated on a daily basis for a small catchment (Catchment-25) of the

20 Dhrabi watershed without any soil conservation structures. Statistical measures ( $R^{2}$ and EN-S) were used to evaluate model performance; the model performed satisfactorily well for both surface runoff and sediment yield estimations, with the $\mathrm{R}^{2}$ and EN-S values both being greater than 0.75, during calibration (2009-2010) and validation (2011). The model was applied to various small watershed sites in the Chakwal and Attock districts after successful calibration and validation. Soil erosion estimation was performed at these sites having loose stone soil and water conservation structures and being under various slope

25 gradient and vegetation cover conditions. The structures had significant effects, and the average sediment yield reduction engendered by the loose stone structures at the various sites varied from 54 to $98 \%$. The sediment yield and erosion reductions were also compared under conditions involving vegetation cover change. Agricultural land with winter wheat crops had a higher sediment yield level than did fallow land with crop residue, which facilitated sediment yield reduction along with the soil conservation structures. Analyzing various slope gradients revealed that all selected sites had a maximum slope area of

30 less than $5 \%$; stone structures were installed at these sites to reduce sediment yield. Based on slope classification analysis, the model was upscaled for the whole districts of Chakwal and Attock. The results indicated that $60 \%$ of Chakwal $\left(4095 \mathrm{~km}^{2}\right)$ and Attock $\left(3918 \mathrm{~km}^{2}\right)$ by area lies in a slope range of 0-4\%; this thus implies that considerable potential exists for implementing soil conservation measures by installing stone structures. Estimates revealed that minimum sediment yield reductions of 122,850 t year ${ }^{-1}$ in Chakwal District and 117,540 t year ${ }^{-1}$ in Attock District could be achieved by installing 
Hydrol. Earth Syst. Sci. Discuss., https://doi.org/10.5194/hess-2017-532

Manuscript under review for journal Hydrol. Earth Syst. Sci.

Discussion started: 24 October 2017

(c) Author(s) 2017. CC BY 4.0 License.

loose stone structures in $60 \%$ of the agricultural areas of both districts having a slope of 0-4\%; these findings can serve as a reference for policymakers and planners. The overarching findings of this study show that the SWAT model provides reliable results for sediment yield and soil erosion estimation, which can be used in rocky mountainous watersheds for erosion control and watershed management.

5 Keywords: SWAT Modeling, Soil Erosion, Land Management, Soil Conservation Structures, Model Upscaling

\section{Introduction}

Water and soil are the most crucial natural resources for agriculture and livestock production, playing key roles in the economic growth of any region. Studies have shown that agricultural soils are the alluvial deposits formed through the weathering of mountains and transported through wind and water. However, when anthropogenic activities disturb fertile soil formation, this

10 can lead to soil physiognomy degradation, soil productivity reduction, and crop production loss; this ultimately instigates problems in agroecological farming systems and environment watershed plans (Panomtaranichagul and Nareuban, 2005). Considerable increases in sediment yield at the expense of soil renewal pose a major threat to soil and water resources development. Although water erosion is a function of many environmental factors, its assessment and mitigation at the watershed level are complex phenomena; this is because of the unpredictable nature of rainfall along with topographic

15 heterogeneities and climate and land use-land cover variability, as well as other catchment features for the specified areas under study (Moore and Burch, 1986). In addition, inappropriate land management practices and human activities increase the dynamics of these factors (Wischmeier and Smith, 1978). Modern tools used for soil erosion estimation are based on physical, empirical, or conceptual models at the watershed level; however, the current models have some limitations. For example, the Universal Soil Loss Equation (USLE) is the empirical model used because it is easy to apply and has low data requirements;

20 nevertheless, it exhibits deficiencies in simulating physical processes in a watershed. By contrast, the Water Erosion Prediction Project model is a physically based hydrological model that provides a complete understanding and quantification of physical processes; however, it is typically used on small watersheds (between 10 and $100 \mathrm{~km}^{2}$ ) and requires a large amount of data (Kliment et al., 2008). A conceptual model such as the Soil and Water Assessment Tool (SWAT) is an empirically derived physically based model that exemplifies a compromise between empirical and physical model algorithms (Borah and Bera,

25 2003); furthermore, it is considered a more suitable tool for agricultural management practices in watersheds, compared with other models.

Agricultural land degradation in rainfed mountainous areas is a major onsite problem that also causes offsite effects such as downstream sediment deposition in fields, floodplains, and water bodies. Globally, water resources deterioration caused by soil erosion is a growing concern; an estimated productivity loss of US\$13-28 billion annually in drylands can be attributed

30 to soil erosion (Scherr and Yadav, 1996). Urbanization, deforestation, overgrazing, and improper tillage practices that leave the land fallow with low organic matter are the major causes of soil erosion and produce serious economic loss for the nation (Ashraf et al., 2002). Soil erosion is a direct function of slope length and steepness, because of direct increases in flow velocity 
Hydrol. Earth Syst. Sci. Discuss., https://doi.org/10.5194/hess-2017-532

Manuscript under review for journal Hydrol. Earth Syst. Sci.

Discussion started: 24 October 2017

(c) Author(s) 2017. CC BY 4.0 License.

(van Vliet and Hall, 1995). Vegetation cover on sloped ground helps reduce soil loss; however, during field preparation and cultivation, the surface soil becomes pulverized and easily eroded, causing acute topsoil erosion because of vegetation cover removal. Therefore, during the cultivation of sloping land, measures should be adopted to stop fertile surface soil erosion caused by substantial rainfall runoff. If such measures are not applied, the agricultural land may turn barren in only a few years

5 (Itani, 1998). Vegetation cover is a key measure for soil protection against water erosion (Uhlirova and Podhrazska, 2007; Gordon et al., 2008; Saco et al., 2007); it reduces the flow velocity of surface runoff by increasing surface roughness, in addition to increasing the infiltration rate (Hejduk and Kasprzak, 2004, 2005) of soil.

Soil erosion and water loss are extreme hazards in rainfed areas of Pakistan because of the uneven topography in such areas, in which agriculture is directly dependent on rainfall. According to Rafiq (1984), 76 \% of Pakistan's area is affected by various

10 types of erosion; for example, $36 \%$ is affected by water erosion and $40 \%$ by wind erosion.

Determining the relationship between rainfall runoff and soil erosion is imperative in the Pothwar rainfed region for creating applicable soil and water conservation mechanisms, as well as for enhancing crop productivity. Considering the long-term sustainability and productivity of eroded land, the present study focused on the Pothwar plateau (Chakwal and Attock districts) having an arid to semiarid climate, according to a soil survey report (Ali, 1967). Generally, the plateau land comprises broken

15 gullies, low hill ranges, and a flat to gently undulating topography. The textural classification varies from sandy to silt and clay loam, and the land consists of poor to fertile soil derived from sandstone and loess parent material (Nizami et al., 2004). The rainfall pattern is unpredictable with high intensity; 60-70\% of the total rainfall occurs during the monsoon season (from mid-June to mid-September). After the rains, soil crusting decreases the infiltration rate and aeration and increases soil strength, which reduces plant emergence and exposes the soil surface to erosion (Shafiq et al., 2005). The soil loss rate becomes more

20 deleterious with higher intensity rainfall runoff over greater slope lengths and steepness levels (Rai and Mathur, 2007). The highest estimated record of soil erosion was $150-165 \mathrm{t} \mathrm{ha}^{-1}$ year $^{-1}$ in the Dhrabi watershed in part of the Pothwar region (Ashraf et al., 2002). Without adequate protection, the effects of erosion on this highly erodible soil are extensive fertile soil and vegetation loss, endangered soil and water conservation structures, and reservoir depletion through sedimentation. Moreover, it causes doubts about the viability of existing and future soil and water conservation schemes. If ignored, untimely

25 soil erosion and sedimentation can reduce benefits and may lead to prohibitively expensive remedial measures. The Pothwar region consists of cultivated highland slopes where timely soil and water conservation strategies and remedial measures are the basic requirements for sustainable crop productivity. In this study, the SWAT model was applied to assess sediment yield in small watersheds of the Pothwar region, as well as to evaluate the effect of loose stone soil conservation structures.

\subsection{SWAT model description}

30 The SWAT is a comprehensive, semidistributed, physically based, basin-scale hydrological model that assesses land-soilwater-plant systems (Arnold et al., 1998; Neitsch et al. 2001). It is commonly used to simulate water and soil loss in small agricultural watersheds (Tripathi et al., 2003). Neitsch et al. (2001) discussed the model's development, operation, assumptions, 
Hydrol. Earth Syst. Sci. Discuss., https://doi.org/10.5194/hess-2017-532

Manuscript under review for journal Hydrol. Earth Syst. Sci.

Discussion started: 24 October 2017

and limitations in the SWAT theoretical documentation and user's manual available on the SWAT website (USDA-ARS, 2002). Srinivasan et al. (1998) reviewed the SWAT model simulation and application for streamflow, sediment, and nutrient transport along with the effects of management practices. The model simulates hydrology parameters and sediment yield in each hydrologic response unit (HRU). The surface runoff computation is performed using a modified USDA-SCS Curve

5 Number method (USDA-SCS, 1972) or the Green and Ampt infiltration method (Green and Ampt, 1911). Sediment yield levels from each HRU are estimated using the Modified Universal Soil Loss Equation written as a mass balance equation as follows (Williams, 1975; Williams and Berndt, 1977):

$$
\mathrm{S} . \mathrm{Y}=11.8\left(\mathrm{Q}_{\text {surf }} \times \mathrm{q}_{\text {peak }} \times \text { area }_{\text {hru }}\right)^{0.56} \cdot \mathrm{K}_{\mathrm{USLE}} \cdot \mathrm{C}_{\mathrm{USLE}} \cdot \mathrm{P}_{\mathrm{USLE}} \cdot \mathrm{LS}_{\mathrm{USLE}} \cdot \mathrm{CFRG}
$$

where S.Y = sediment yield $\left(\mathrm{t} \mathrm{ha}^{-1}\right)$; $\mathrm{Q}_{\text {surf }}=\operatorname{surface}$ runoff $\left(\mathrm{mm} \mathrm{ha}^{-1}\right)$; $\mathrm{q}_{\text {peak }}=$ peak discharge $\left(\mathrm{m}^{3} \mathrm{~s}^{-1}\right)$; and area hru $=$ area of

10 hydrological response unit (ha). KUSLE, CUSLE, PUSLE, and LSUSLE are USLE parameters and are presented in Table1.

The sediment yield level at a watershed outlet is affected by two principal channel processes: sediment aggradation and degradation. The sediment transport capacity is a direct function of the channel peak velocity, which is used in the SWAT model as shown in Eq. (2):

$$
T_{c h}=\alpha v^{b}
$$

15 where $T_{c h}\left(\mathrm{t} \mathrm{m}^{-3}\right)=$ transport capacity of a channel; $\mathrm{v}\left(\mathrm{m} \mathrm{s}^{-1}\right)=$ channel peak velocity; and $\alpha$ and $\mathrm{b}=$ constant coefficients. The channel peak velocity is calculated using Manning's formula in a reach segment as presented in Eq. (3):

$$
v=\frac{1}{n} R_{c h}{ }^{2 / 3} S_{c h}{ }^{1 / 2}
$$

where $\mathrm{n}=$ Manning's roughness coefficient; $R_{c h}(\mathrm{~m})=$ hydraulic radius; and $S_{c h}\left(\mathrm{~m} \mathrm{~m}^{-1}\right)=$ channel bed slope.

Channel aggradation $\left(\operatorname{Sed}_{\text {agg }}\right)$ and channel degradation $\left(\operatorname{Sed}_{d e g}\right)$ in tons are computed in the channel segment using the criteria

presented in Eqs. (4) and (5):

$$
\begin{aligned}
& \text { if } \operatorname{sed}_{i}>T_{c h}: \operatorname{Sed}_{\text {agg }}=\left(\operatorname{sed}_{i}-T_{c h}\right) \times V_{c h} \& \operatorname{Sed}_{d e g}=0 \\
& \text { if } T_{c h}<\operatorname{sed}_{i}: \operatorname{Sed}_{d e g}=\left(T_{c h}-\operatorname{sed}_{i}\right) \times V_{c h} \times K_{c h} \times C_{c h} \& \operatorname{Sed}_{\text {agg }}=0
\end{aligned}
$$

where $\operatorname{sed}_{i}\left(\mathrm{t} \mathrm{m}^{-3}\right)=$ initial concentration of sediment; $C_{c h}=$ channel cover factor; $K_{c h}\left(\mathrm{~cm} \mathrm{~h}^{-1} \mathrm{~Pa}^{-1}\right)=$ channel erodibility factor; and $V_{c h}\left(\mathrm{~m}^{3}\right)=$ channel segment water volume.

25 ( Sed $\left._{\text {out }}\right)$ in tons is the total sediment transported out of the channel segment, which is computed using Eq. (6):

$$
\operatorname{Sed}_{\text {out }}=\left(\operatorname{sed}_{i}+\operatorname{Sed}_{\text {deg }}-\operatorname{Sed}_{\text {agg }}\right) \times \frac{V_{\text {out }}}{V_{\text {ch }}}
$$

where $V_{\text {out }}\left(\mathrm{m}^{3}\right)=$ volume of water leaving the channel segment at each time step.

\subsubsection{Portrayal of study area}

This study was conducted in subcatchments of Chakwal and Attock districts to optimize the micro watersheds for soil erosion

estimation using the SWAT model. First, the model was calibrated and validated in the subcatchment (Catchment-25) of the Dhrabi Watershed, Chakwal District, Pothwar. Catchment-25 is an agricultural watershed consisting of deep gullies and having 
Hydrol. Earth Syst. Sci. Discuss., https://doi.org/10.5194/hess-2017-532

Manuscript under review for journal Hydrol. Earth Syst. Sci.

Discussion started: 24 October 2017

an area of 2 ha and elevation ranging from 527.15 to $539.78 \mathrm{~m}$ above sea level. It has well-defined boundaries and wide gully beds that mimic the full representation of the study area. The soil texture class is sandy loam and rainfall ranges from 450 to $630 \mathrm{~mm}$. The watershed outlet as the measuring point has the coordinates $32.8946380 \mathrm{~N}$ and $72.7094070 \mathrm{E}$, as shown in Fig. 1.

5 The SWAT model was applied to the following sites for estimating the soil erosion in watersheds with water conservation structures:

1. Kohkar Bala

2. Khandoya

3. Dhoke Mori (Khaliq Gulli, Ashraf Gulli)

$10 \quad 4 . \quad$ Chak Khushi

5. Dhoke Dhamal

6. Dhoke Hafiz Abad

Sites 1 to 4 are located in Chakwal District, whereas sites 5 and 6 are in Attock District, as shown in Fig. 2a and b. The topography of the area made it difficult to assess the selected site. The structures were installed in the gullies and small fields.

15 Considerable effort was required to accurately delineate the watershed for estimating the HRU and subbasins.

\section{Materials and methods}

\subsection{Required data and their collection}

To model sediment yield, two types of input data were required: (1) spatial raster data, including digital elevation model (DEM), mask DEM, land use, and soil and slope data; and (2) daily meteorological and climatic data in a lookup table and observed

20 runoff and sediment data. For this study, Catchment-25 was used for sediment yield evaluation because of the similar characteristics of its selected small watersheds. A physical topographical survey of the catchment was conducted using a global positioning system (GPS), and a DEM was then generated using point-source elevation data in a geographic information system by applying the inverse distance weighting method. The soil, sandy loam, is composed of $67 \%$ sand, $19 \%$ silt, and $14 \%$ clay. The catchment features deep gullies with scrub trees, bushes, and grasses on top. The vegetation cover consists of the saroot

25 (Saccharum bengalense) shrubs, phulahi (Acacia modesta) trees, dab (Desmostachya bipinnata) and khavi grass, and khabbal (Cynodon dactylon).

Meteorological, measured runoff, and sediment data for the period 2009-2011 were collected from the Soil and Water Conservation Research Institute (SAWCRI), Chakwal District Department. The department installed an automatic weather station, water-level recorder for runoff, and stilling basin for sediment (see Oweis and Ashraf (eds.) (2012)). 
Hydrol. Earth Syst. Sci. Discuss., https://doi.org/10.5194/hess-2017-532

Manuscript under review for journal Hydrol. Earth Syst. Sci.

Discussion started: 24 October 2017

Hydrology and

Earth System

(c) Author(s) 2017. CC BY 4.0 License.

Sciences

Discussions

(c) $\underset{\mathrm{BY}}{\mathrm{B}}$

\subsection{Model setup and simulation}

After the SWAT model established, the first step in measuring the catchment's topography was physiographic analysis. ArcSWAT was used to delineate subwatersheds automatically and generate a stream network based on the DEM. An appropriate database of subbasin parameters and comprehensive topographic reports of the watershed were generated. SWAT

5 coding conventions were used to reclassify land use and soil maps. The model's predictions are highly sensitive to HRU distribution levels (Mamillapalli, 1998); therefore, the distribution levels were set to $0 \%$, and the watershed was classified into HRUs based on the unique land use and soil and slope class in the overlaying section. The weather station location table and lookup tables of daily precipitation and temperature (maximum and minimum) data were loaded to link them with the required files. The model was initially simulated using default parameter values for surface runoff and sediment yield. Event

10 base model calibration (2009-2010) and validation (2011) were performed using the parameters in Table.1

\section{Results and discussion}

\subsection{Model calibration and validation}

Calibration involves the adjustment of parameters in watershed modeling; model predictions obtained without calibration may differ substantially from observed data. Various options and techniques are available for SWAT model calibration. In this

15 study, the SWAT calibration procedure of Santhi et al. (2001a) was adopted. The statistical measures used in the model evaluation were the coefficient of efficiency (EN-S) (Nash and Sutcliffe, 1970) and coefficient of determination $\left(\mathrm{R}^{2}\right)$. The EN$\mathrm{S}$ value ranges from $-\infty$ to 1 ; the simulation results are considered good if the EN-S value is $>0.75$ and satisfactory if the EN$\mathrm{S}$ is in the range 0.36-0.75 (Motovilov et al., 1999). The model prediction is considered unacceptable if the EN-S value is negative or nearly 0 (Santhi et al., 2001a). The $\mathrm{R}^{2}$ value ranges from 0 to 1 , with higher values representing stronger predication

20 and agreement. An $\mathrm{R}^{2}$ value of 1 indicates a perfect correlation between observed data and model simulations.

Both calibration (2009-2010) and validation (2011) processes were performed manually on an event basis by using the soil erosion parameter values provided in Table 2. For the calibration process, the parameter ranges were referenced from Neitsch et al. (2001) and the calibration criteria followed those of Santhi et al. (2001a).

Table 3 presents the model performance in terms of surface runoff and sediment yield, as evaluated using statistical indicators

25 ( $\mathrm{R}^{2}$, EN-S). This table indicates that the model performed reasonably well for the small watershed (Catchment-25) in the Pothwar region. Furthermore, high $\mathrm{R}^{2}$ values were observed, indicating a strong correlation between the observed and simulated runoff and sediment yield. EN-S values signifying the observed and predicted runoff and sediment yield plots fit the 1:1 line well. The calibration and validation results for surface runoff are illustrated in Fig. 3a and b, respectively, and those for sediment yield are illustrated in Fig. $4 \mathrm{a}$ and b, respectively.

30 In 2009, a total rainfall of $400 \mathrm{~mm}$ was observed to accumulate from 11 erosive rainstorms. The maximum rainstorm (108 $\mathrm{mm}$ ) occurred on July 29 , producing a $46.2 \mathrm{~mm}$ runoff and a $6.86 \mathrm{t} \mathrm{ha}^{-1}$ sediment yield. The total measured runoff was 95.5 
Hydrol. Earth Syst. Sci. Discuss., https://doi.org/10.5194/hess-2017-532

Manuscript under review for journal Hydrol. Earth Syst. Sci.

Discussion started: 24 October 2017

(c) Author(s) 2017. CC BY 4.0 License.

$\mathrm{mm}$, and the runoff values ranged between 0.24 and $46.2 \mathrm{~mm}$ (Fig. 3a). The total sediment yield was $13.2 \mathrm{t} \mathrm{ha}^{-1}$, and the yield values ranged between 0.003 and $6.86 \mathrm{tha}^{-1}$ against the corresponding events (Fig. 4a).

From February to September 2010, 13 erosive storms occurred with a total rainfall of $528.3 \mathrm{~mm}$. The observed overall runoff during the 2010 measuring period was $129.53 \mathrm{~mm}$, with runoff events ranging from 0.31 to $31.5 \mathrm{~mm}$ (Fig. 3a). The maximum rainstorm $(122.3 \mathrm{~mm})$ occurred on the same date as the previous year, generating a $25.9 \mathrm{~mm}$ surface runoff and $7.75 \mathrm{tha}^{-1}$ sediment yield. The rainfall event on July $29(122.3 \mathrm{~mm})$ and August $24(62.8 \mathrm{~mm})$ produced relatively low runoff values of 25.9 and $20.3 \mathrm{~mm}$, as well as low erosion rates of 7.75 and $5.15 \mathrm{tha}^{-1}$, respectively. By contrast, the rainfall event on July 20 $(59.9 \mathrm{~mm})$ produced a maximum amount of runoff $(31.5 \mathrm{~mm})$ and sediment yield $\left(9.04 \mathrm{t} \mathrm{ha}^{-1}\right)$, although the soil was not wet from a prior rainfall event, whereas for the other two storms, the soil was wet from prior rainfall events (Fig. 3a and Fig. 4a).

10 The total soil loss during the 2010 investigation period was $31.13 \mathrm{tha}^{-1}$, with the loss values ranging between 0.016 and 9.041 $\mathrm{tha}^{-1}$.

During the validation period, 12 erosive rainfall events occurred with a total rainfall amount of $262 \mathrm{~mm}$, which produced an overall runoff of $28.34 \mathrm{~mm}$ and sediment yield of $2.59 \mathrm{t} \mathrm{ha}^{-1}$. The maximum rainstorm (39.6 mm) occurred on August 12, causing a $7.48 \mathrm{~mm}$ runoff and $0.598 \mathrm{t} \mathrm{ha}^{-1}$ soil loss, as illustrated in Fig. $3 \mathrm{~b}$ and Fig. 4b. The observed runoff and soil loss

15 during the validation period were lower because of light rainstorms.

According to the comparisons of the simulated and measured sediment yield and runoff during the calibration and validation periods (Fig. 3a and b and Fig. 4a and b), the average simulated runoff $(6.73 \mathrm{~mm}$ ) was close to the average observed runoff $(7.04 \mathrm{~mm})$, whereas the average simulated sediment yield was nearly equal to the average observed sediment yield $(1.30 \mathrm{t}$ $\mathrm{ha}^{-1}$ ). Furthermore, the mean values and standard deviations revealed good agreement between the simulated and observed

20 sediment yield and surface runoff values for the calibration and validation periods. The validated model was subsequently used to assess model applicability for soil erosion estimation with conservation structures under various scenarios.

\subsection{Model application with conservation structures}

After the model validation with adjusted soil erosion parameters, the model was applied to the aforementioned small watersheds. These small watersheds already have existing soil and water conservation structures for assessing soil erosion. All of the structures are of loose stone apron type without steel wire meshing and have similar geometry to a weir-type spillway. The crests of the structures play a major role in reducing the flow velocity that creates ponding and results in sediment deposition (erosion reduction) upstream of the structures, whereas the downstream sections of the structures prevent channel or gully development. Using a GPS and total station (Fig. 5), this study marked the point elevation data and boundaries of all watersheds; because of the complex topography of the small watersheds, considerable effort was required to accurately delineate the watershed area for estimating the HRU and subbasins (for example, at the Khokar Bala site). After preparation 
Hydrol. Earth Syst. Sci. Discuss., https://doi.org/10.5194/hess-2017-532

Manuscript under review for journal Hydrol. Earth Syst. Sci.

Discussion started: 24 October 2017

(C) Author(s) 2017. CC BY 4.0 License.

of the requisite data file for SWAT model input, the model was run for all the selected sites for 6 years from January 2010 to April 2015.

\subsection{Soil erosion estimation and effect of conservation structures}

The validated model was run without and with conservation structures separately for each selected site. Sediment yield results

5 were compared under each condition, as shown in Table 5, by modifying the SWAT parameters representing the conservation structures, as shown in Table 4. Soil and water conservation structures, such as loose stone structures and stone bunds, act as imperative measures in the reduction of flow velocity, surface runoff, soil erosion, and slope length in a watershed system (Bracmort et al., 2006). Apposite parameters that signify the effect and importance of loose stone structures are the average slope length (SLSUBBSN), land management practice parameter (USLE_P), and curve number (CN2) for rainfall runoff

10 conversion (Betrie et al., 2011). During the establishment of the SWAT model, these three parameters were modified manually; the SLSUBBSN value was modified by editing the HRU (.hru) input table, whereas CN2 and USLE_P were altered in the management input file (.mgt). Three more parameters were modified, namely average slope steepness (HRU_SLP) of the HRU input tables and two basin parameters (SPCON and SPEXP) representing the general watershed attributes in the Basin (.bsn) input files. The six parameters were modified according to the slope characteristics of the small watersheds and field conditions,

15 in addition to being modified according to the terraced and contoured section of the SWAT user's manual (Neitsch et al., 2005) and a literature review (Betrie et al., 2011; Herweg and Ludi, 1999; Hurni, 1985).

Table 5 presents a significant sediment yield reduction achieved by incorporating the parameter values recommended for stone structures. The average annual sediment yield reduction varied from 40 to $90 \%$ in the analyzed sites; the Khokar Bala site showed the maximum reduction. The average 5-year sediment yield reduction engendered by structures at various sites was

20 revealed to vary from 54 to $98 \%$; these results are relatively comparable to the findings of various scientists (e.g., Betrie et al., 2011; Gebremichael et al., 2005; Herweg and Ludi, 1999). Betrie et al. (2011) indicated 6-69 \% sediment reductions in the Upper Blue Nile River basin caused by stone bunds. A field-scale study in the northern part of Ethiopia by Gebremichael et al. (2005) indicated a $68 \%$ sediment yield reduction engendered by stone bunds. In addition, Herweg and Ludi (1999) conducted a study at plot scale in the Eritrean highlands and Ethiopia and reported $72-100 \%$ sediment yield reductions engendered by stone bunds.

The effect of conservation structures on sediment yield reduction is elucidated in a report by Oweis and M. Ashraf (eds.) (2012): "Stone spillways as conservation measures were designed and installed in the Dhrabi Watershed of Chakwal District to reduce soil erosion; analysis results revealed that, on average, water at a height of approximately $10-15 \mathrm{~cm}$ was retained in the fields by the stone spillway structures, thus reducing soil erosion by reducing the kinetic energy of the runoff." Regarding

30 the effectiveness of the soil conservation structures (stone structures) installed in the Dhrabi watershed, the average soil loss rates in 2009 without and with structures were calculated as 47 and $37.98 \mathrm{t} \mathrm{ha}^{-1}$ year ${ }^{-1}$, respectively, with a $20 \%$ reduction. However, the maximum soil loss rates without and with structures were 2716.17 and $1731 \mathrm{t} \mathrm{ha}^{-1}$ year $^{-1}$, respectively, with a 
Hydrol. Earth Syst. Sci. Discuss., https://doi.org/10.5194/hess-2017-532

Manuscript under review for journal Hydrol. Earth Syst. Sci.

Discussion started: 24 October 2017

$37 \%$ reduction. Similarly, a $31 \%$ reduction in average soil loss and a $36 \%$ reduction in maximum soil erosion were reported for the year 2010 in the same catchment (Klik et al., 2012). Nabi et al. (2008) reported that in the Soan River basin of Pothwar, the soil loss rates in barren and shrub land were 63.41 and $53.41 \mathrm{t} \mathrm{ha}^{-1}$ year ${ }^{-1}$, respectively, whereas those in low- and highcultivation land were 34.91 and $25.89 \mathrm{tha}^{-1}$ year $^{-1}$, respectively.

\section{$5 \quad 3.4$ Soil erosion estimation under different scenarios}

In addition to evaluating the effectiveness of the soil conservation structures as presented in Table 5, this study developed various scenarios to estimate the further reduction in soil erosion associated with various types of land use change in the studied catchment areas. The scenarios were developed according to the scientific literature of land use and vegetation cover importance to assess soil erosion. Vegetation cover increases the infiltration rate (Hejduk and Kasprzak, 2004, 2005), reduces

10 the erosive velocity of surface runoff, and plays a key role in resisting water erosion. A trivial variation in vegetative cover can produce considerable effects in overland flow (Wei et al., 2011). Vegetation cover is a key factor in controlling and reducing surface runoff and water erosion on agricultural land (Hofman et al., 1985).

The SWAT model was applied on the basis of four scenarios at the Dhoke Mori (Khaliq and Ashraf Gulli) and Khandoya catchment sites. The scenarios are described as follows:

15 Scenario 1 (S1): The model was applied for soil erosion estimation on land without structures under the following conditions: the land use type was determined to be winter wheat; for overland flow, Manning's $n=0.15$ (for short grass), and for channel flow, Manning's n $=0.025$ (for natural, earth uniform streams).

Scenario 2 (S2): The model was applied for soil erosion estimation on land with structures under the same conditions as S1.

Scenario 3 (S3): The model was applied for soil erosion estimation on fallow land without structures. Manning's $n=0.09$ for

20 overland flow. Crop residue and channel flow conditions remained the same.

Scenario 4 (S4): The model was applied for soil erosion estimation on land with structures under the same conditions as S3.

The analysis of the various scenarios revealed that the sediment yield level was higher in S1 and S2 than in S3 and S4. This indicates that the sediment yield level is higher on agricultural land than on fallow land with crop residue. In the comparative analysis of $\mathrm{S} 1$ and $\mathrm{S} 2$, the average sediment yield decreased to $1.25 \mathrm{tha}^{-1}$, whereas in $\mathrm{S} 3$ and $\mathrm{S} 4$ (fallow land with crop residue),

25 the average sediment yield decreased to $0.85 \mathrm{t} \mathrm{ha}^{-1}$. The results reveal that land use change facilitates sediment yield reduction, in addition to soil conservation structures.

Notably, a visual observation of the various structures revealed that the effects of the structures on soil erosion control generally extended to a 4 to $5 \mathrm{~m}$ radius from the center of the structure crests during high flow seasons; the water accumulated and sediment was deposited upstream of the structures. 
Hydrol. Earth Syst. Sci. Discuss., https://doi.org/10.5194/hess-2017-532

Manuscript under review for journal Hydrol. Earth Syst. Sci.

Discussion started: 24 October 2017

(c) Author(s) 2017. CC BY 4.0 License.

\subsection{Model upscaling for Attock and Chakwal districts}

As reported by various researchers, soil loss is minimal on sloping land with vegetation cover; however, when the available vegetation cover is removed, soil loss becomes more significant as a function of slope length and slope steepness. The stream power (TU) as a function of shear stress and flow velocity and the shear stress caused by flowing water are the basic criteria for assessing erosion of soil particles caused by overland flow. Shear stress and flow velocity are directly proportional to slope steepness. This means that the steeper the land slope is, the greater the shear stress becomes, consequently increasing the potential for soil erosion.

Additionally, when soil conservation structures are installed in a field, farmers focus on cultivating agricultural crops in the areas above and below such structures. Considering these factors, this study estimated the potential area that would benefit

10 from the installation of structures in Chakwal and Attock. Accordingly, the model was upscaled and soil erosion reduction was estimated at the district level by determining suitable slopes for stone structures and agricultural practices. The areas under various slopes in the small watersheds were calculated and are shown in Table.7

All selected sites in the catchment were depicted as having a maximum slope area of less than $5 \%$. This is because the selected sites were used for agricultural production. Farmers have graded the land as suitable for crop production and generating less

15 surface runoff. The agriculture practices are only possible on soil that has a slope of less than $8 \%$; otherwise, land grading must be carried out. The same has been suggested by various authors; a USLE experiment conducted at the SAWCRI office concluded that only a slope of less than $10 \%$ is acceptable for agricultural practices under rainfed conditions.

The total maximum and minimum sediment yield reductions are provided in Table. 8

The maximum proportions of the areas in Attock District and Chakwal District with less than 20\% slope were 94 and $94.5 \%$,

20 respectively. The table shows that approximately $61 \%\left(3918 \mathrm{~km}^{2}\right)$ of Attock District lies in a slope range of $0-4 \%$, whereas $28 \%\left(1786 \mathrm{~km}^{2}\right)$ lies in a slope range of $4-10 \%$. This $89 \%$ area has a potential minimum sediment yield reduction of 171,120 $\mathrm{t} \mathrm{year}^{-1}$ if soil conservation structures are constructed. Similarly, $60 \%\left(4095 \mathrm{~km}^{2}\right)$ of Chakwal District lies in a slope range of 0-4\%, whereas $28 \%\left(1913 \mathrm{~km}^{2}\right)$ of Chakwal District lies in a slope range of 4-10\%, which means a potential minimum sediment yield reduction of 180,240 t year $^{-1}$. The minimum slope areas were considered according to Betrie et al. (2011), who

25 recommended that stone bunds should be applied in low-slope areas for soil conservation. However, the effectiveness of the structures depends on the local topography and soil and land use-land cover conditions. Considering topographic conditions, considerable potential exists for implementing soil conservation measures through the installation of stone structures. However, appropriate maintenance of the structures is crucial for sustaining effectiveness.

\section{Conclusions and Recommendations}

30 The following conclusions were reached: 
Hydrol. Earth Syst. Sci. Discuss., https://doi.org/10.5194/hess-2017-532

Manuscript under review for journal Hydrol. Earth Syst. Sci.

Discussion started: 24 October 2017

(c) Author(s) 2017. CC BY 4.0 License.

1. Loose stone structures are effective options for soil erosion control in rainfed areas. The model results reveal that $40-$ $90 \%$ sediment yield reduction could be achieved using soil conservation structures.

2. An all-inclusive interpretation of the quantitative model results may be misleading because no model can simulate all physical processes of soil and water interactions in a real sense. Some assumptions were made during modeling; however, the results suggest to policymakers and planners that more than $60 \%$ of the area in Attock and Chakwal districts has potential for soil conservation using stone structures.

3. The conservation structures require regular maintenance because nonmeshing can cause stones to slide, which may lead to the displacement of the whole structures.

4. The structures were not designed according to the hydraulic characteristics of surface flow. Downstream damage of the structures was common because of the nonavailability of downstream energy dissipation arrangements.

5. Considering the topographic conditions, loose stone structures should be installed in areas with a slope range of 0-10 $\%$.

6. Wire-meshed stone structures should be installed in areas with a slope range of 6-10\%. Proper energy dissipation arrangements should be implemented to prevent downstream erosion.

\section{Acknowledgments}

This study is part of a research project under the CGIAR Research Program (CRP on Dryland Systems) carried out through cooperation between University of Engineering and Technology, Centre for Excellence in Water Resources Engineering, The International Center for Agriculture Research in the Dry Areas, and Soil and Water Conservation Research Institute. The authors particularly thank all colleagues involved in the fieldwork. This manuscript was edited by Wallace Academic Editing.

\section{Author contributions}

Ghulam Nabi was in charge of designing the study and wrote the paper. Fiaz Hussain performed the analysis and produced the results. Ray-Shyan Wu helped in strengthening the quality of the work in terms of data management and result evaluation. The authors Vinay Nangia, Riffat Bibi, and Abdul Majid contributed to the preparation and review of the manuscript.

\section{Conflicts of interest}

25 The authors declare no conflict of interest. 
Hydrol. Earth Syst. Sci. Discuss., https://doi.org/10.5194/hess-2017-532

Manuscript under review for journal Hydrol. Earth Syst. Sci.

Discussion started: 24 October 2017

(c) Author(s) 2017. CC BY 4.0 License.

\section{References}

Ali, M.A.: Reconnaissance Soil Survey of Rawalpindi Area. Soil Survey of Pakistan, Lahore, 1967.

Arnold, J. G., R. Srinivasan, R.S. Muttiah, and J.R. Williams.: Large-area hydrologic modeling and assessment: Part I. Model development. J. Amer. Water Res. Assoc. 34(1): 73-89, 1998.

5 Ashraf, M., F.U. Hassan, A. Saleem, and M. Iqbal M.: Soil conservation and management: a prerequisite for sustainable agriculture in Pothwar. Science, Technology and Development 21(1): 25-31, 2002.

Betrie. G.D, Mohamed. Y. A., van Griensven. A., and R. Srinivasan.: Sediment management modelling in the Blue Nile Basin using SWAT model. Hydrol. Earth Syst. Sci., 15, 807-818, www.hydrol-earth-syst-sci.net/15/807/2011/ doi:10.5194/hess15-807-2011, 2011.

10 Borah, D.K. and M. Bera.: Watershed-Scale Hydrologic and Nonpoint-Source Pollution Models: Review of Mathematical Bases. Trans. ASAE 46(6): 1553-1566, 2003.

Bracmort, K., Arabi, M., Frankenberger, J., Engel, B., and Arnold, J.: Modeling long-term water quality impact of structural BMPs, T. ASABE, 49, 367-374, 2006.

Gebremichael, D., Nyssen, J., Poesen, J., Deckers, J., Haile, M., Govers, G., and Moeyersons, J.: Effectiveness of stone bunds 15 in controlling soil erosion on cropland in the Tigray highlands, Northern Ethiopia, Soil Use. Manage., 21, 287-297, 2005.

Gordon, J.M., S.J. Bennett, C.V. Alfonso and R.L. Bingner.: Modeling long term soil losses on agricultural fields due to ephemeral gully erosion. Journal of Soil and Water Conservation 63: 173-181, 2008

Green, W.H. and G.A. Ampt.: Studies on Soil Physics, 1. The Flow of Air and Water Through Soils. Journal of Agricultural Sciences 4:11-24, 1911.

20 Hejduk, S. and K. Kasprzak.: Advantages and risks of grassland stand from the viewpoint of flood occurrence. Grassland Science in Europe 9: 228-230, 2004.

Hejduk, S. and K. Kasprzak.: A contribution to proposals of the width of protective grasslands strips. Soil and Water Conservation 4: 30-35, 2005.

Herweg, K. and Ludi, E.: The performance of selected soil and water conservation measures-case studies from Ethiopia and

25 Eritrea, Catena, 36, 99-114, 1999.

Hofman I, Ries RF, Gilley GE.: Relationship of Runoff and Soil Loss to Ground Cover of Native and reclaimed grazing land. Agron. J., 75: 599-607, 1985.

Hurni, H.: Erosion - productivity - conservation systems in Ethiopia, in: Proceedings of the 4th International Conference on Soil Conservation, Maracay, Venezuela, 654-674, 1985.

30 Itani, J.: Evaluation of an indigenous farming system in the Matengo Highlands, Tanzania, and its sustainability. African Study Monographs 19(2): 55-68, 1998.

Klik, A., W. Rattanaareekul, and T. Bushsbaum.: Soil erosion assessment in Dhrabi watershed. ICARDA, Aleppo, Syria. Xviii + 205 pp, ISBN: 92-9127-269-8, (2012). 
Hydrol. Earth Syst. Sci. Discuss., https://doi.org/10.5194/hess-2017-532

Manuscript under review for journal Hydrol. Earth Syst. Sci.

Discussion started: 24 October 2017

Hydrology and

Earth System

(c) Author(s) 2017. CC BY 4.0 License.

Sciences

Discussions

(c) $($ P)

Kliment, Z., J. Kadlec and J. Langhammer.: Evaluation of suspended load changes using AnnAGNPS and SWAT semiempirical erosion models. Catena 73: 286-299, 2008.

Mamillapalli, S.: Effect of Spatial Variability on River Basin Stream Flow Modeling. Ph.D. Thesis, Purdue University, West Lafayette, Indiana, 1998.

5 Moore, I.D. and G.J Burch.: Physical basis of the length-slope factor in the Universal Soil Loss Equation. Soil Science Society of America Journal 50: 1294-1298, 1986.

Motovilov YG, Gottschalk L, Engeland K, Rodhe A.: Validation of distributed hydrological model against spatial observations. Agric For Meteorol 98(1):257-277, 1999.

Nabi, G., M. Latif., M. Ahsan and S. Anwar.: Soil erosion estimation of Soan river catchment using remote sensing and

10 geographic information system. Paper published in Soil \& Environment, formerly Pakistan Journal of Soil Science. Vol. 27, No. 1, 2008.

Nash, J.E. and J.V. Sutcliffe.: River Flow Forecasting Through Conceptual Models Part 1: A Discussion of Principles. Journal of Hydrology 10:282-290, 1970.

Neitsch JG, Arnold JG, Kiniry JR, Williams JR.: Soil and Water Assessment Tool, Theoretical Documentation - Version 2000

15 Blackland Research Center - Texas, 2001.

Neitsch, S. L., Arnold, J. G., Kiniry, J., and Williams, J. R.: Soil and water assessment tool theoretical documentation (Version 2005), USDA Agricultural Research Service and Texas A\&M Blackland Research Center, Temple, Texas, 2005.

Nizami, M.A., M. Shafiq, A. Rashid and M. Aslam.: The soils and their agricultural development potential in Pothwar. WRRILRRP, National Agricultural Research Centre, Islamabad, Pakistan. 158 p, 2004.

20 Panomtaranichagul, M. and S. Nareuban.: Improvement of water harvesting and anti-erosive cultural practices for sustainable rainfed multiple crop production on sloping land. Conference on International Agricultural Research for Development, Stuttgart-Hohenheim. October 11-13, 2005, Tropentag 2005, Stuttgart Hohenheim, Germany.

Rafiq M.: Presentation report of operational watershed management Project, Pakistan Agricultural Research Council, Islamabad, Pakistan, 1984.

25 Rai, R.K. and B.S. Mathur.: Event based soil erosion modeling of small watersheds. Journal of Hydrologic Engineering 12: 6$7,2007$.

Saco PM, Willgoose GR, Hancock GR.: Eco-geomorphology of banded vegetation patterns in arid and semi-arid regions. Hydrol. Earth Syst. Sci., 11: 1717-1730, 2007.

Santhi, C., J.G. Arnold, J.R. Williams, W.A. Dugas, R. Sirinivasan, and L.M. Hauck.: Validation of the SWAT Model on a

30 Large River Basin with Point and Nonpoint Sources. Journal of the American Water Resources Association (JAWRA) 37(5): 1169-1188, 2001a.

Scherr, S. J. and S. Yadav.: Land degradation in the developing world: implications for food, agriculture and the environment to 2020. Food, Agriculture and the Environment Discussion Paper 14. IFPRI, Washington, DC, USA, 1996. 
Hydrol. Earth Syst. Sci. Discuss., https://doi.org/10.5194/hess-2017-532

Manuscript under review for journal Hydrol. Earth Syst. Sci.

Discussion started: 24 October 2017

Shafiq, M., A. Rashid and A.G. Mangrio.: Agricultural potential soil resources of Pothwar Plateau. Soil and Environment 24: 109-119, 2005.

Sirinivasan, R., T.S. Ramanarayanan, J.G. Arnold, and S.T. Bednarz.: Large Area Hydrologic Modeling and Assessment Part II: Model Application. Journal of the American Water Resources Association (JAWRA) 34(1):91-101. System Sciences 11: 5 1717-1730, 1998.

T. Oweis, M. Ashraf.: Assessment and Options for Improved Productivity and Sustainability of Natural Resources in Dhrabi Watershed Pakistan. ICARDA, Aleppo, Syria. xviii + 205 pp.77, (eds, 2012).

Tripathi, M.P., R.K. Panda, and N.S. Raghuwanshi.: Identification and Prioritization of Critical Sub watersheds for Soil Conservation Management using the SWAT Model. Bio-systems Engineering 85(3):365-379, doi:10.1016/S1537-

$10 \quad 5110(03) 00066-7,2003$.

Uhlirova, J. and J. Podhrazska.: Evaluation of efficiency of the flood and erosion protecting measurements. Pozemkové úpravy 61: 10-12, 2007.

USDA-ARS (U.S. Department of Agriculture-Agricultural Research Service):: Soil and Water Assessment Tool: SWAT. Available at http://www.brc.tamus.edu/swat/. Accessed in January 2005.

15 USDA-SCS (U.S. Department of Agriculture-Soil Conservation Service).: National Engineering Handbook Section 4 Hydrology. U.S. Department of Agriculture-Soil Conservation Service, Washington, D.C. 1972.

van Vliet, L.J.P. and J.W. Hall.: Effects of planting direction of Brussels sprouts a previous cultivation on water erosion in southwestern British Columbia, Canada. Journal Soil and Water Conservation 50: 188-192, 1995.

Wei M, Bogaard TA, Beek R.: Dynamic effects of vegetation on the long-term stability of slopes: components of evaporation.

20 Geophysical Res. Abstracts., 13: 7720-7725, 2011.

Williams and H.D. Berndt.: Sediment yield prediction based on watershed hydrology, Trans. ASAE (1977), pp. 1100-1104

Williams, J.R.: Sediment-Yield Prediction with Universal Equation Using Runoff Energy Factor. In: Present and Prospective

Technology for Predicting Sediment Yield and Sources. Proceedings of the Sediment Yield Workshop, USDA Sedimentation Lab., Oxford, Mississippi, November 28-30, 1972, ARS S-40, pp.244-252, 1975.

25 Wischmeier, W.H., Smith, D.D.: Predicting Rainfall Erosion Losses, A Guide to Conservation, Agricultural Handbook 537. Planning, Science and Education Administration. US Department of Agriculture, Washington, DC, 58 pp, 1978.

www.met-office.gov.uk/research/hadleycentre/pubs/brochures/B1999/imp_water_res.html 
Hydrol. Earth Syst. Sci. Discuss., https://doi.org/10.5194/hess-2017-532

Discussion started: 24 October 2017

Table 1. Soil erosion estimation parameters used in ArcSWAT

\begin{tabular}{lll}
\hline S. No. & Parameter & Description \\
\hline 1 & USLE_P & USLE conservation practice factor \\
2 & USLE_C & Cover and management factor in USLE \\
3 & USLE_K & USLE Soil erodibility factor \\
4 & SPCON & Linear parameter for calculating the maximum amount of \\
& & sediment that can be re-entrained during channel sediment \\
& & routing \\
& SPEXP & Exponent parameter for calculating sediment re-entrained \\
5 & & in channel sediment routing \\
& Channel Erodibility factor \\
7 & CH_COV & Channel Cover factor \\
\end{tabular}

Table 2. Soil erosion parameters used during model calibration and validation

\begin{tabular}{llc}
\hline Parameter & Default Value & Value Used \\
\hline USLE_P & 0 to 1 & 0.11 \\
USLE_C & 0.001 to 0.5 & 0.182 \\
USLE_K & 0 to 0.65 & 0.246 \\
SPEXP & 1.0 to 2.0 & 1.0 \\
SPCON & 0.0001 to 0.01 & 0.0032
\end{tabular}

Table 3. SWAT model performance evaluation

\begin{tabular}{lcc}
\hline Surface Runoff & & \\
\hline Parameter & Calibration & Validation \\
\hline $\mathrm{R}^{2}$ & 0.84 & 0.81 \\
EN-S & 0.81 & 0.78 \\
\hline Sediment Yield & & \\
\hline $\mathrm{R}^{2}$ & 0.82 & 0.79 \\
$\mathrm{EN}-\mathrm{S}$ & 0.79 & 0.76 \\
\hline
\end{tabular}

Table 4. SWAT parameters used to represent conservation structures

\begin{tabular}{ll}
\hline Parameter Name (input file) & Modified Value \\
\hline SLSUBBSN (.hru) & 60
\end{tabular}


Hydrol. Earth Syst. Sci. Discuss., https://doi.org/10.5194/hess-2017-532

Manuscript under review for journal Hydrol. Earth Syst. Sci.

Discussion started: 24 October 2017

(c) Author(s) 2017. CC BY 4.0 License.

(c) (1)
HRU_SLP (.hru)
0.016
CN2 (.mgt)
65
USLE_P (.mgt)
0.65
SPCON (.bsn)
0.001
SPEXP (.bsn)
1.25

Table 5. Effect of stone structures on sediment yield reduction

Sediment Yield (t/ha) Reduction due to Stone Structures

\begin{tabular}{|c|c|c|c|c|c|c|c|c|c|c|c|c|c|c|c|}
\hline \multirow[b]{2}{*}{$\underset{\nabla}{\tilde{\Xi}}$} & \multicolumn{3}{|c|}{ Khaliq Gulli } & \multicolumn{3}{|c|}{ Ashraf Gulli } & \multicolumn{3}{|c|}{ Khokar Bala } & \multicolumn{3}{|c|}{ Chak Khushi } & \multicolumn{3}{|c|}{ Dhoke Dhamal } \\
\hline & $\begin{array}{l}n \\
0 \\
0 \\
3\end{array}$ & 3 & $\begin{array}{l}\overrightarrow{0} \\
\simeq \\
0\end{array}$ & $\begin{array}{l}n \\
0 \\
3 \\
3\end{array}$ & 3 & $\begin{array}{l}\overrightarrow{0} \\
\simeq \\
0\end{array}$ & $\begin{array}{l}n \\
0 \\
3 \\
3\end{array}$ & 3 & $\begin{array}{l}\vec{d} \\
\widetilde{\alpha} \\
0\end{array}$ & $\begin{array}{l}n \\
0 \\
3 \\
3\end{array}$ & 3 & $\begin{array}{l}\overrightarrow{0} \\
\simeq \\
0 \\
0\end{array}$ & $\begin{array}{l}0 \\
0 \\
3 \\
3\end{array}$ & $\stackrel{2}{3}$ & $\begin{array}{l}\vec{d} \\
\stackrel{2}{2} \\
0\end{array}$ \\
\hline 2010 & 59.3 & 30.3 & 49.0 & 25.0 & 10.4 & 58.5 & 37.6 & 0.9 & 97.6 & 1.6 & 0.8 & 49.4 & 15.3 & 8.3 & 45.7 \\
\hline 2011 & 25.8 & 15.3 & 40.6 & 10.7 & 2.6 & 75.8 & 21.9 & 0.4 & 98.1 & 0.9 & 0.4 & 58.8 & 6.7 & 2.3 & 66.3 \\
\hline 2012 & 2.3 & 0.0 & 100 & 0.9 & 0.0 & 100 & 3.9 & 0.1 & 98.5 & 0.0 & 0.0 & 100 & 0.6 & 0.0 & 98.2 \\
\hline 2013 & 32.9 & 14.6 & 55.7 & 14.0 & 3.5 & 75.2 & 28.7 & 0.7 & 97.7 & 1.1 & 0.2 & 78.2 & 8.9 & 2.2 & 75.0 \\
\hline 2014 & 27.6 & 11.9 & 57.0 & 11.6 & 2.2 & 81.1 & 13.8 & 0.2 & 98.6 & 0.8 & 0.2 & 69.7 & 7.4 & 1.8 & 75.4 \\
\hline 2015 & 34.0 & 25.2 & 25.9 & 14.5 & 3.0 & 79.0 & 21.1 & 0.3 & 98.8 & 0.9 & 0.1 & 92.1 & 9.4 & 0.9 & 90.3 \\
\hline Ave. & - & - & 54.7 & - & - & 78.3 & - & - & 98.2 & - & - & 74.7 & - & - & 75.2 \\
\hline
\end{tabular}

Table 6. Effect of different scenarios on sediment yield reduction

\begin{tabular}{llllllc}
\hline $\begin{array}{l}\text { Catchment } \\
\text { Name }\end{array}$ & $\begin{array}{l}\mathrm{S} 1 \\
(\mathrm{t} / \mathrm{ha})\end{array}$ & $\begin{array}{l}\mathrm{S} 2 \\
(\mathrm{t} / \mathrm{ha})\end{array}$ & S.Y Reduction & $\begin{array}{l}\mathrm{S} 3 \\
(\mathrm{t} / \mathrm{ha})\end{array}$ & $\begin{array}{l}\mathrm{S} 4 \\
(\mathrm{t} / \mathrm{ha})\end{array}$ & S.Y Reduction \\
\hline Ashraf Gulli & 10.95 & 10.15 & $0.80 \mathrm{t} / \mathrm{ha}$ & 7.91 & 7.04 & $0.86 \mathrm{t} / \mathrm{ha}$ \\
Khaliq Gulli & 25.98 & 24.75 & $1.23 \mathrm{t} / \mathrm{ha}$ & 17.10 & 16.5 & $0.60 \mathrm{t} / \mathrm{ha}$ \\
Khandoya & 48.75 & 47.0 & $1.75 \mathrm{t} / \mathrm{ha}$ & 42.28 & 41.18 & $1.1 \mathrm{t} / \mathrm{ha}$ \\
\hline
\end{tabular}

Table 7. Area under different slopes in small watersheds of Chakwal and Attock districts 
Hydrol. Earth Syst. Sci. Discuss., https://doi.org/10.5194/hess-2017-532

Manuscript under review for journal Hydrol. Earth Syst. Sci.

Discussion started: 24 October 2017

(C) Author(s) 2017. CC BY 4.0 License.

\begin{tabular}{lllllll}
\hline & $\begin{array}{l}\text { Ashraf } \\
\text { Gully }\end{array}$ & $\begin{array}{l}\text { Khaliq } \\
\text { Gully }\end{array}$ & $\begin{array}{l}\text { Chak } \\
\text { Khushi }\end{array}$ & $\begin{array}{l}\text { Dhok } \\
\text { Dhamal }\end{array}$ & Khokar Bala \\
\hline $\begin{array}{l}\text { Slope } \\
(\%)\end{array}$ & Area (\%) & $\begin{array}{l}\text { Area } \\
(\%)\end{array}$ & $\begin{array}{l}\text { Area } \\
(\%)\end{array}$ & Area $(\%)$ & $\begin{array}{l}\text { Slope } \\
(\%)\end{array}$ & $\begin{array}{l}\text { Area } \\
(\%)\end{array}$ \\
\hline $0-2$ & 63 & 50 & 97 & 81 & $0-5$ & 65 \\
$2-5$ & 30 & 42 & 3 & 17 & $5-10$ & 25 \\
$>5$ & 7 & 8 & - & 1 & $>10$ & 10 \\
\hline
\end{tabular}

Table 8. Sediment yield reduction under different slopes with application of stone structures in Chakwal and Attock districts

\begin{tabular}{lllllllll}
\hline & \multicolumn{7}{c}{ Chakwal } & \multicolumn{7}{c}{ Attock } \\
\cline { 2 - 8 } & Area & Area & $\begin{array}{l}\text { Min S.Y } \\
\text { Reduction }\end{array}$ & $\begin{array}{l}\text { Max S.Y } \\
\text { Reduction }\end{array}$ & Area & Area & $\begin{array}{l}\text { Min S.Y } \\
\text { Reduction }\end{array}$ & $\begin{array}{l}\text { Max S.Y } \\
\text { Reduction }\end{array}$ \\
\hline$(\%)$ & $\mathrm{km} 2$ & $(\%)$ & $(\mathrm{t} / \mathrm{yr})$ & $(\mathrm{t} / \mathrm{yr})$ & $\mathrm{km} 2$ & $(\%)$ & $(\mathrm{t} / \mathrm{yr})$ & $(\mathrm{t} / \mathrm{yr})$ \\
\hline $0-4$ & 4095 & 60 & 122850 & 7944300 & 3918 & 61 & 117540 & 7600920 \\
$4-10.1$ & 1913 & 28 & 57390 & 3711220 & 1786 & 28 & 53580 & 3464840 \\
$10.1-20$ & 547 & 8 & 16410 & 1061180 & 472 & 7 & 14160 & 915680 \\
$20.1-40$ & 233 & 3 & 6990 & 452020 & 165 & 3 & 4950 & 320100 \\
$40-90$ & 75 & 1 & 2250 & 145500 & 55 & 1 & 1650 & 106700 \\
\hline
\end{tabular}


Hydrol. Earth Syst. Sci. Discuss., https://doi.org/10.5194/hess-2017-532

Manuscript under review for journal Hydrol. Earth Syst. Sci.

Discussion started: 24 October 2017

Hydrology and

(c) Author(s) 2017. CC BY 4.0 License.

Discussions

(c) (i)

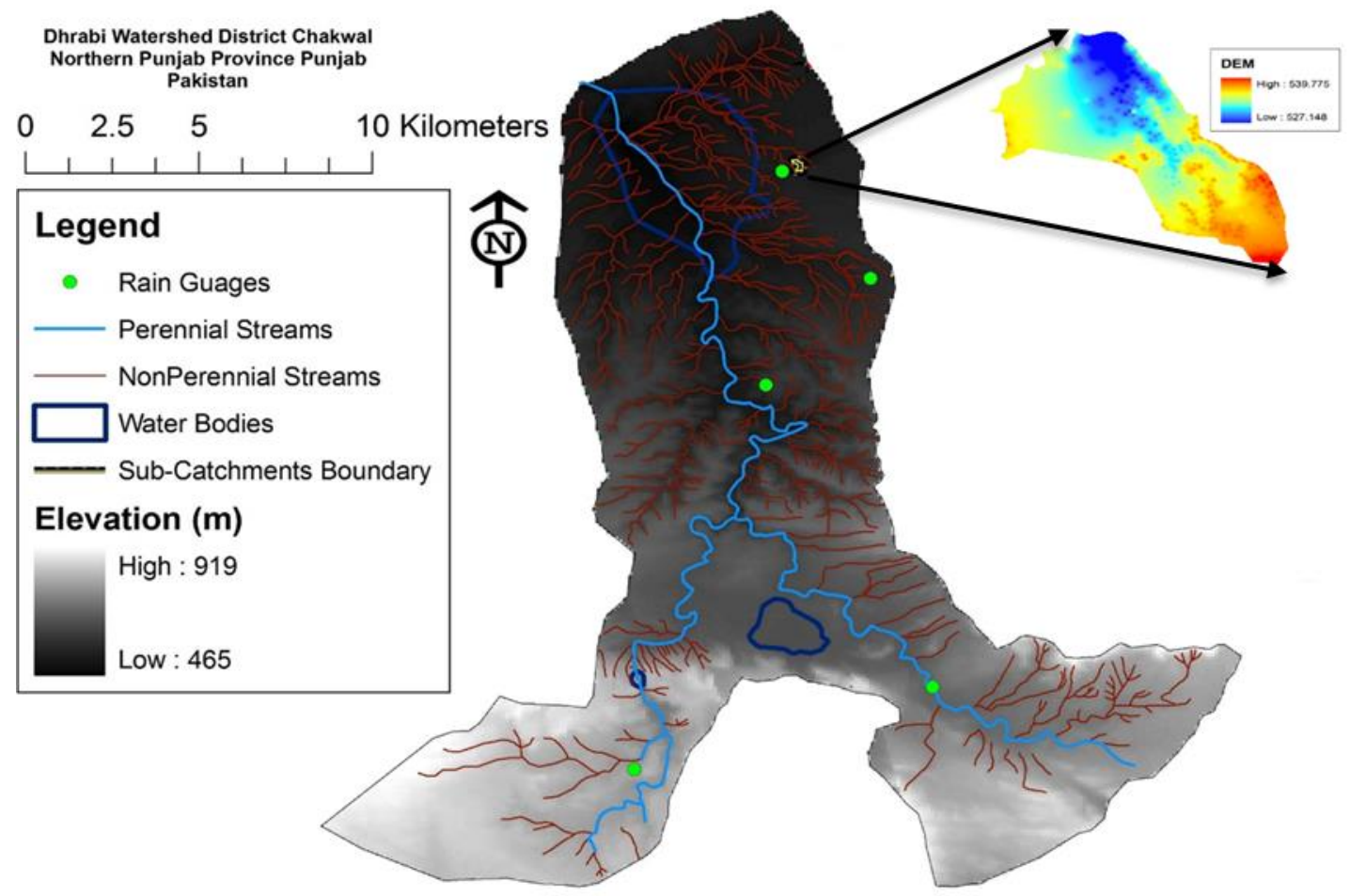

Figure 1. Location of Catchment-25 used for model calibration and validation. 
Hydrol. Earth Syst. Sci. Discuss., https://doi.org/10.5194/hess-2017-532

Manuscript under review for journal Hydrol. Earth Syst. Sci.

Discussion started: 24 October 2017
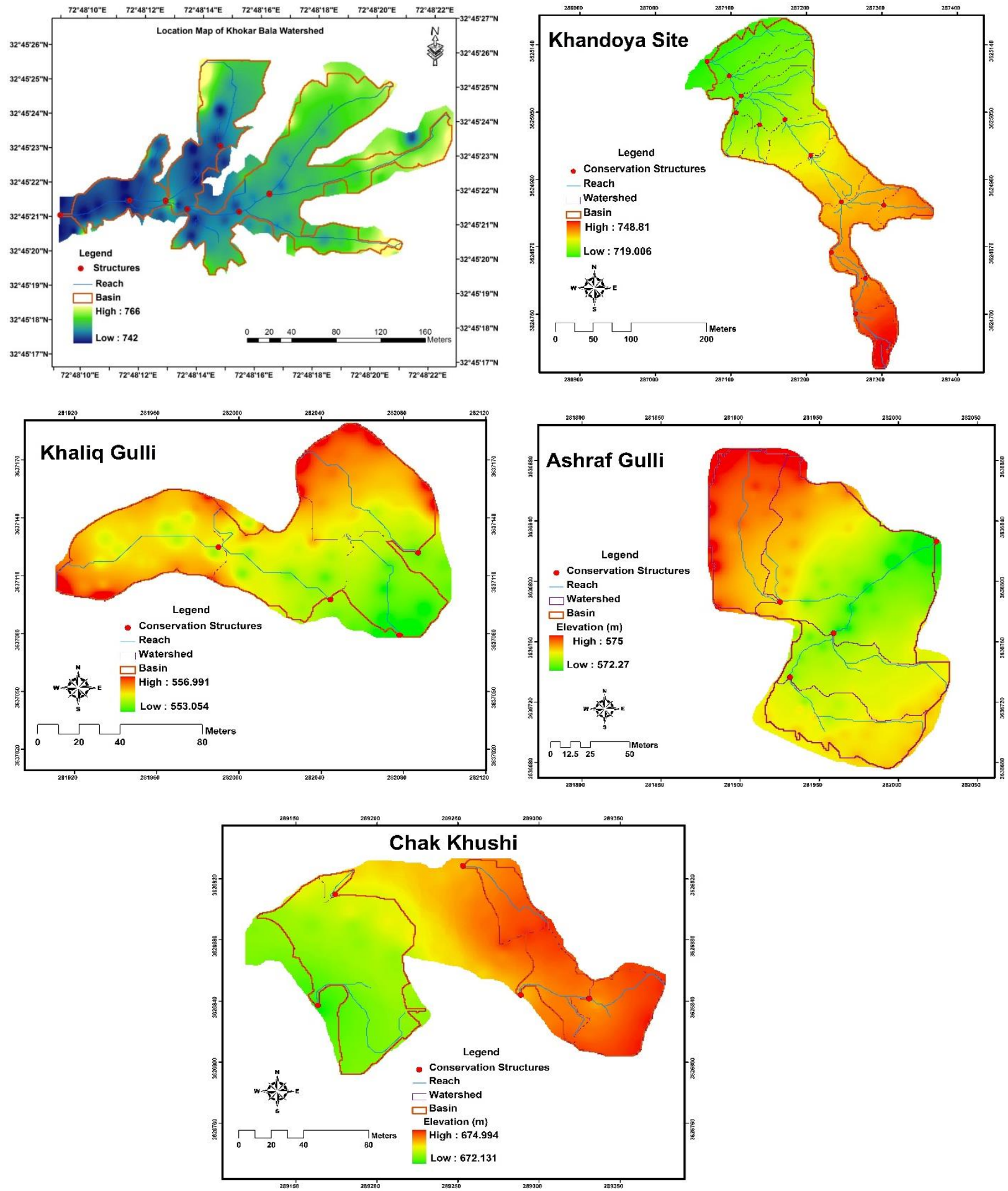

10 Figure 2. (a) Topographic maps of selected small watersheds in Chakwal District for model application. 
Hydrol. Earth Syst. Sci. Discuss., https://doi.org/10.5194/hess-2017-532

Manuscript under review for journal Hydrol. Earth Syst. Sci.

Discussion started: 24 October 2017
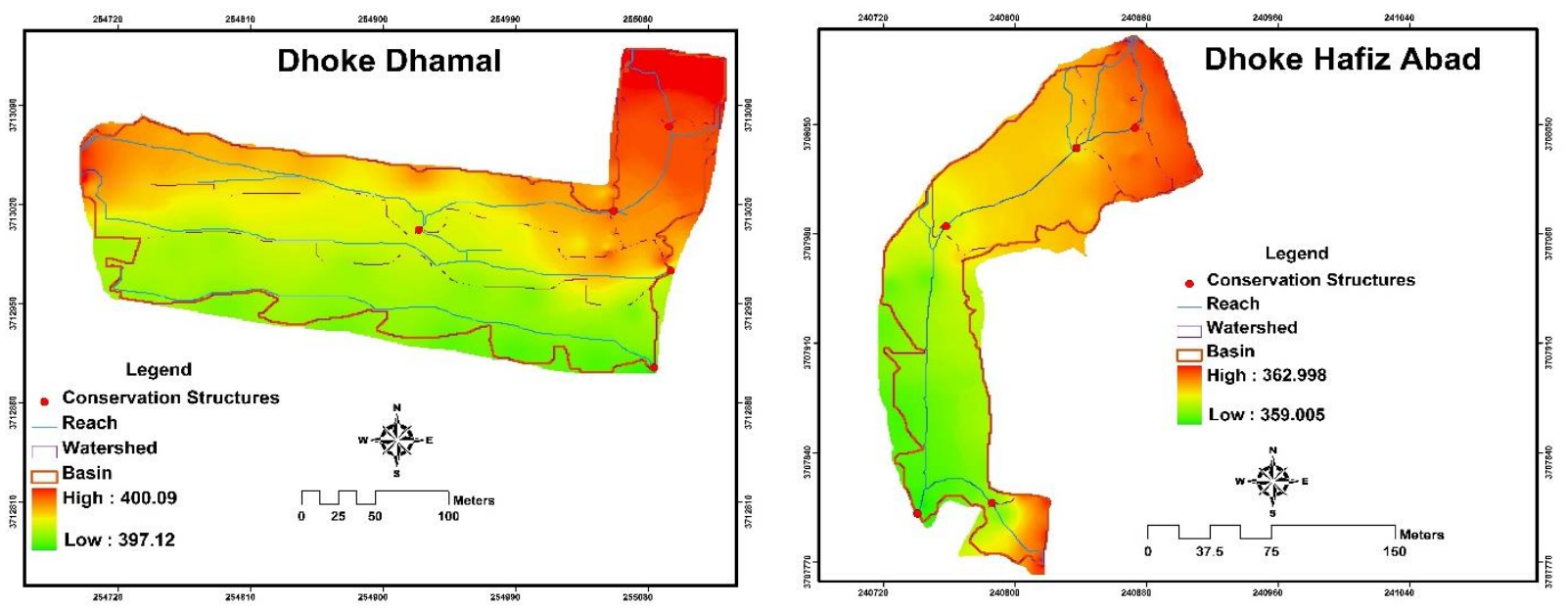

(b) Topographic maps of selected small watersheds in Attock District for model application

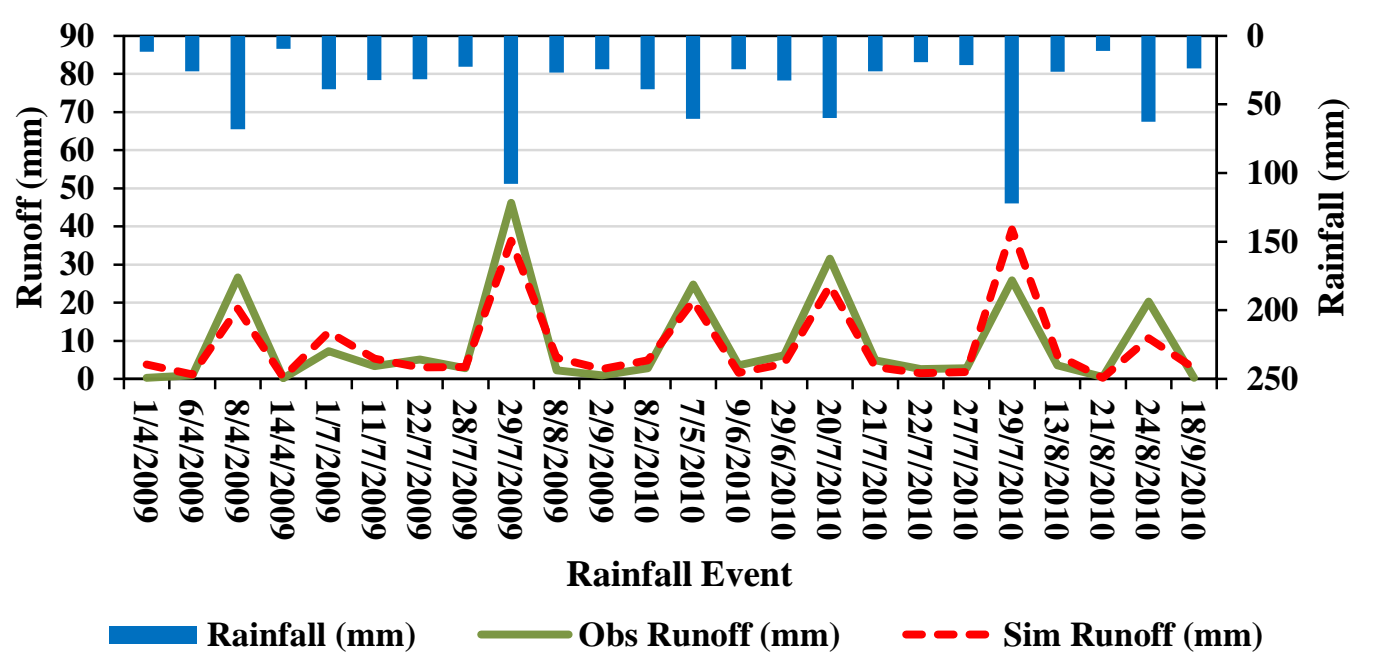

Figure 3. (a) Comparison of observed and simulated runoff for SWAT model calibration 
Hydrol. Earth Syst. Sci. Discuss., https://doi.org/10.5194/hess-2017-532

Manuscript under review for journal Hydrol. Earth Syst. Sci.

Discussion started: 24 October 2017

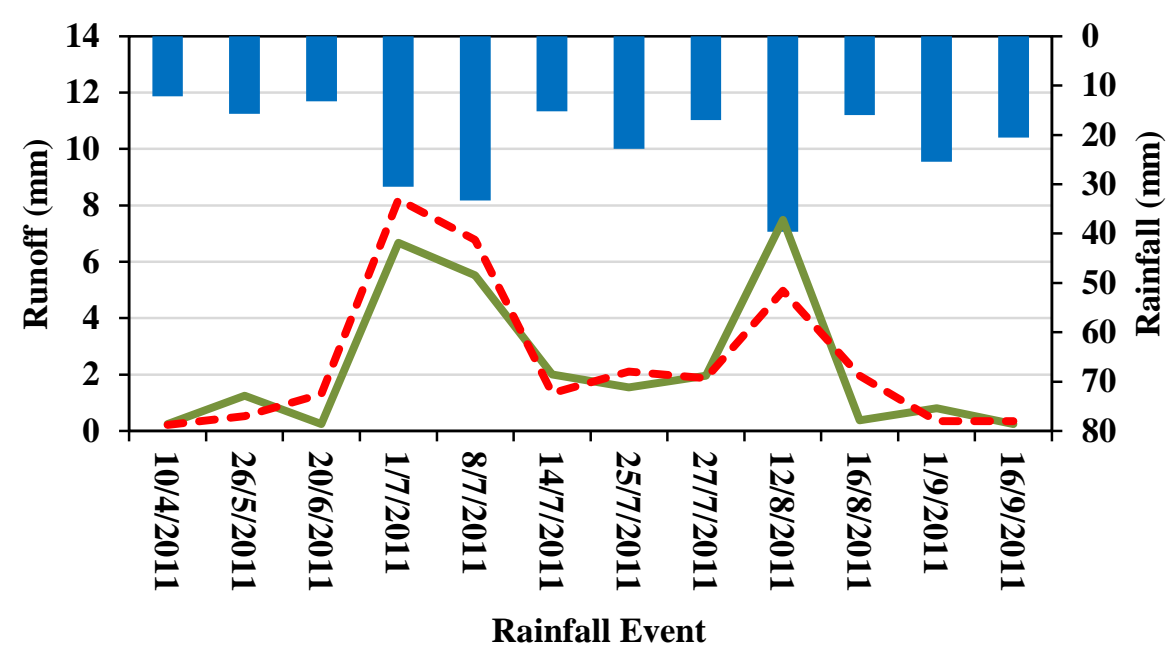

Rainfall (mm) Obs Runoff (mm) - - Sim Runoff (mm)

(b) Comparison of observed and simulated runoff for SWAT model validation

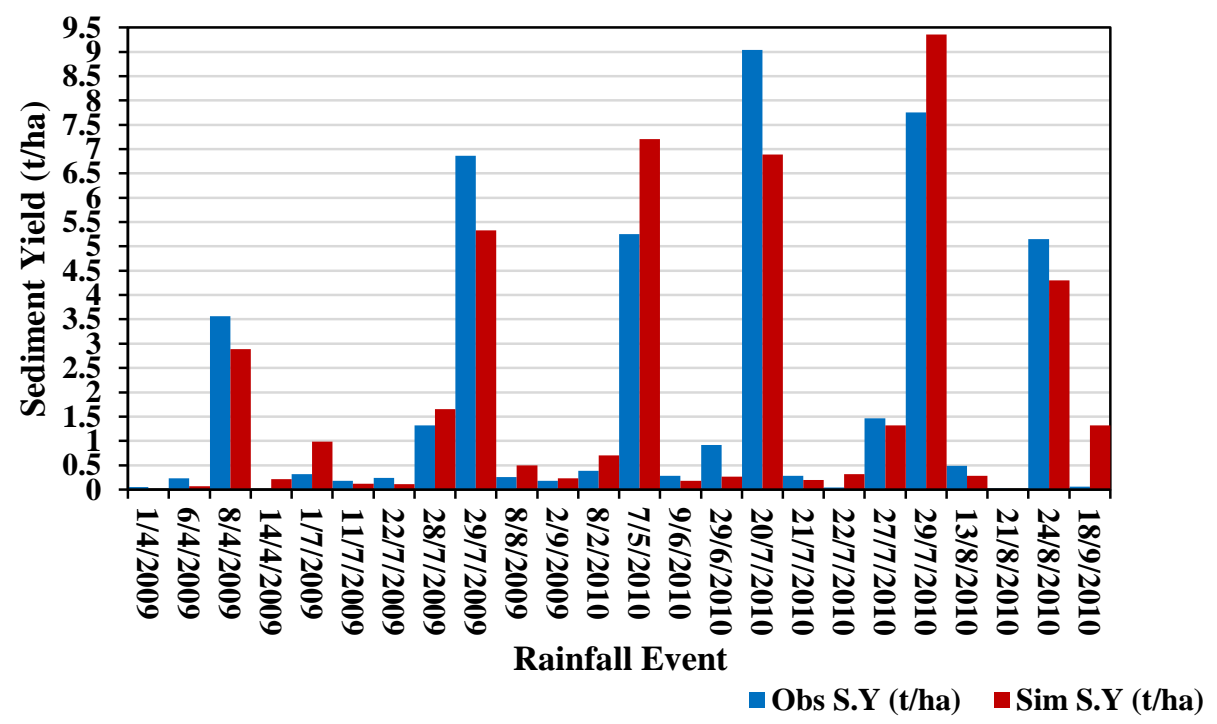

Figure 4. (a) Comparison of observed and simulated sediment yield for SWAT model calibration 
Hydrol. Earth Syst. Sci. Discuss., https://doi.org/10.5194/hess-2017-532

Manuscript under review for journal Hydrol. Earth Syst. Sci.

Discussion started: 24 October 2017

(c) Author(s) 2017. CC BY 4.0 License.
Hydrology and

Earth System

Sciences

Discussions

(c) (1)

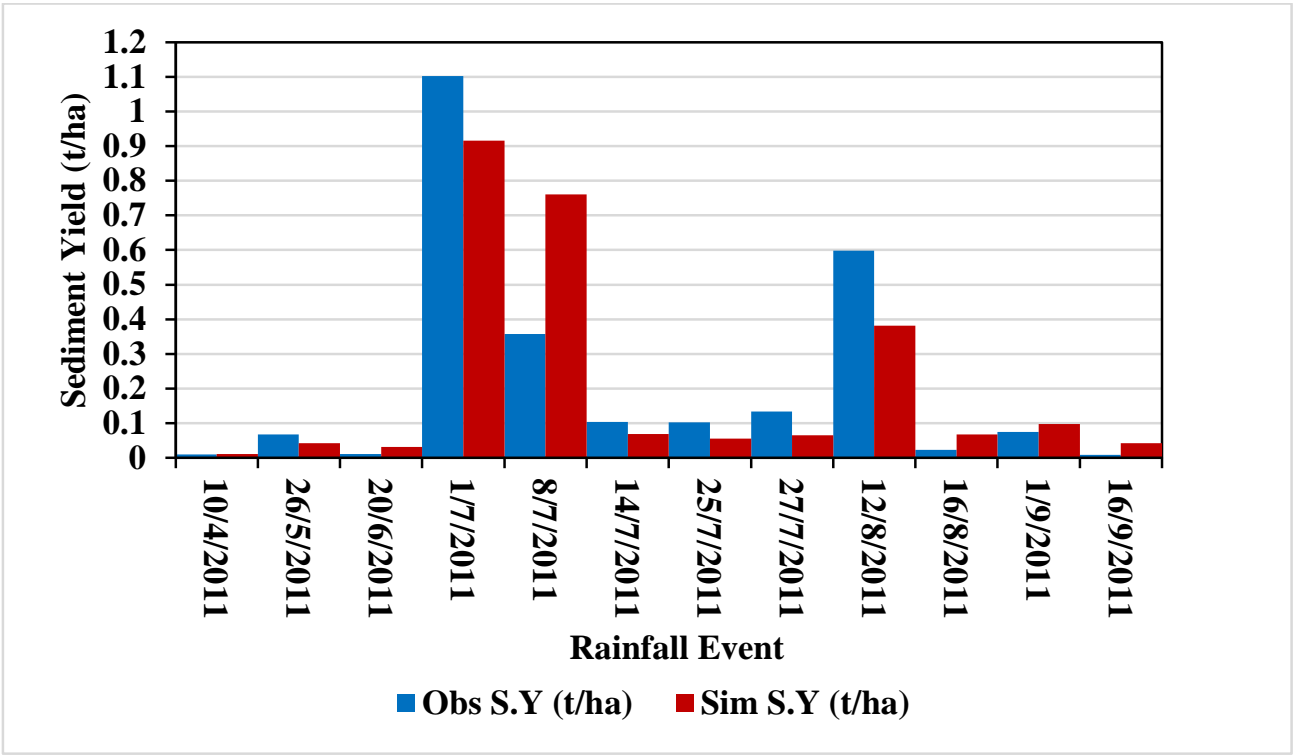

(b) Comparison of observed and simulated sediment yield for SWAT model validation
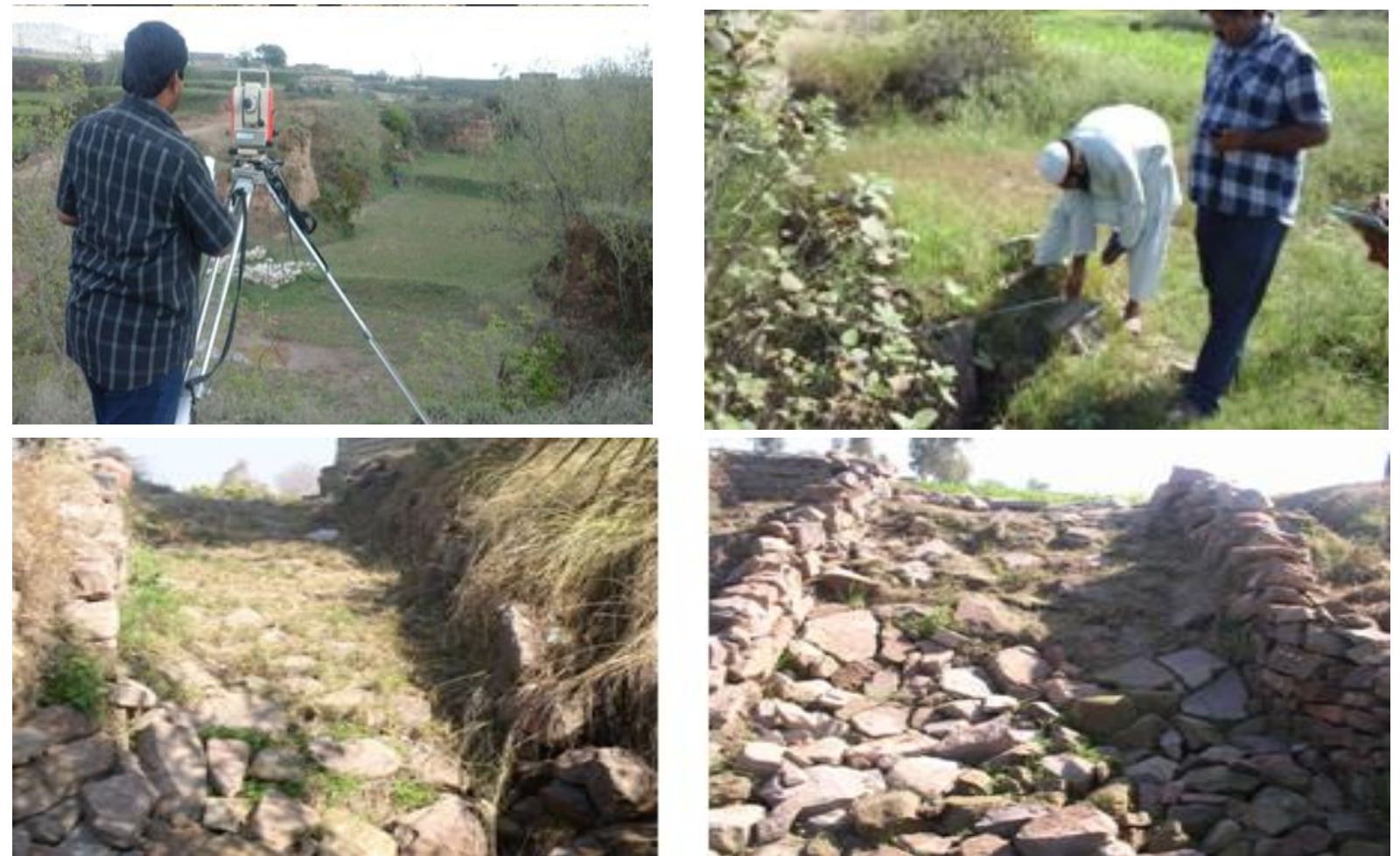

Figure 5. Pictorial view of data collection and conservation structures at different locations 